\title{
Does Dietary Adequacy Reflect the Cognitive Performance of Children? A Study among the Homeless Children in Klang Valley, Malaysia
}

\author{
Chin, K.J. ${ }^{a}$, Asma' $A^{* a}$, Yusof $H M^{a}$, Churak P. ${ }^{b}$, Latiffah $K^{c}$ \\ ${ }^{a}$ School of Food Science \& Technology, Universiti Malaysia Terengganu, Malaysia. \\ binstitute of Nutrition, Mahidol University, Thailand. \\ ${ }^{\mathrm{C}}$ Faculty of Science and Technology, Universiti Sains Islam Malaysia, Negeri Sembilan
}

\section{ABSTRACT}

Introduction: Homeless children are prone to inadequate energy and nutrient intake which may highly influence their cognitive performance. However, few studies have been done in assessing diet adequacy and cognitive performance among homeless children in Malaysia. Materials and Methods: This cross-sectional study aims to assess the dietary adequacy and cognitive performance of 120 homeless children age 7-12 years living in Klang Valley. The dietary adequacy of these homeless children was assessed through two days of 24 hours of dietary recall. Dietary adequacy achievement was determined by fulfilling at least $50 \%$ of Recommended Nutrients Intake (RNI). Raven's Coloured Progressive Matrices (RCPM) test was used to assess their cognitive performance. Results: The homeless children had an adequate intake of energy, iron, zinc, and vitamin B12. Seventy percent of homeless children had a poor cognitive performance. This study shows that there was no association between energy, iron, and vitamin B12 adequacy with cognitive performance, whereas there was a significant $(\mathrm{p}=0.028)$ association between zinc adequacy and children's cognitive performance. Conclusion: These findings provide solid evidence-based for dietary adequacy and cognitive performance of the homeless children in Klang Valley. It is clear from the findings that both dietary intake and cognitive of these children require improvement for a better quality of life in the future. This study suggests that dietary adequacy does not relatively reflect the cognitive performance of these homeless children in Malaysia.

KEYWORDS: dietary adequacy, cognitive performance, homeless children

\section{INTRODUCTION}

The number of homeless people in Klang Valley had dramatically increased from 600 in 2014 to 2000 in 2015. ${ }^{1,2}$ Klang Valley area has the highest number of homeless people at about $35 \% .^{3}$ While a variety of definitions of the term homeless have been suggested, this study will use the definition first suggested by the National Survey of Homeless Assistance Providers and Clients (NSHAPC), in which the homeless are the individuals who live in an emergency shelter, transition house, abandoned buildings, business premises, car or others vehicles,

Corresponding Author:

Dr. Asma' Ali

School of Food Science \& Technology,

Universiti Malaysia Terengganu,

21030 Kuala Nerus, Malaysia

Tel : +609-6684969

Email : asma.ali@umt.edu.my or anywhere outside, or stay permanently under "Program Perumahan Malaysia". ${ }^{4}$

Dietary adequacy compares daily intake with the nutritional requirements of certain individuals or populations. ${ }^{5}$ Adequate intakes that fulfill the recommended nutrient requirement are important for good health, physical growth \& development, and educational performance among children. ${ }^{6}$ Childhood nutrients intake has long-lasting consequences on the children's brain growth and development that leads to better cognitive performance. ${ }^{7}$ Cognitive can be said as the process of gaining knowledge by reasoning or thinking beyond the senses. ${ }^{8}$ Adequate amount of protein, vitamins, and energy sources are vital for the brain to develop and function meritoriously especially during the child growth period. ${ }^{9}$ Besides, deficiency of micronutrients such as iodine, iron, zinc, and vitamin B complex are affecting the growth and development of the brain among children. ${ }^{10,11}$ 
The cognitive development of children is also affected by the deficiency during the brain development period; the maximum brain development is from age 7-15 years old. ${ }^{12}$ During this critical period, children should obtain sufficient nutrition to achieve optimal cognitive performance.

Apart from that, this study needs to be further carried out because it is one of the gaps highlighted in the Nutritional Research Priorities in Malaysia, NRP (2016-2020). The dietary patterns of the homeless have become one of the highlighted gaps under the maternal, infant, and young child nutrition areas. Additionally, there is also a need under the NRP to study the impact of care feeding practices on children's cognitive development, which indicates that it is significant to determine the intake and the cognitive performance of children due to the limited local studies on this issue. Therefore, it is a need to determine levels of diet adequacy among homeless children and their relationship with their cognitive performance.

\section{MATERIALS AND METHODS}

\section{Subject recruitment}

The target population in this study was homeless children in Klang Valley. The sample size for this study was calculated using Cochran's formula below, with a $92 \%$ confidence interval and $8 \%$ precision. The probability in the formula was using the prevalence of iodine deficiency disorder among school children in Malaysia, which is $48.2 \% .^{13}$ Based on the formula, 120 homeless children were required.

\section{Framework Design}

All eligible homeless people who matched the selection criteria were identified for the sampling area purposes. The eligible criteria included the homeless children population registered in an organization, with a fixed building and who did not overlap with other centers points. The respondents included homeless children aged between 7 - 12 years old living in Klang Valley, not bedridden due to illness, and had no physical and mental disabilities. Thus, 11 homeless centers points were eligible and fit the criteria for the study purpose. By using a random sampling method, eleven cards with different homeless people centres points were folded and put in a bowl, and four center points were selected. The cluster sampling method was applied in selecting the respondents for this study. Finally, a total of 120 homeless children were obtained from these four centre points. All respondents were given a subject information sheet, and parental/caregiver consent and child assent were obtained before data collection.

Approval for this study was obtained from the Human Ethics Board of Committees of Universiti Malaysia Terengganu (UMT) before data collection with the reference number of UMT/JKEPM/2018/25. Ethics approval from the Ministry of Education through the online system Educational Research Application System Version 2.0 (eRAS 2.0), Education Department of Federal Territory of Kuala Lumpur, and Social Welfare Department (JKM) were obtained to conduct the study in the selected homeless centres points. The reference number of approval from the Ministry of Education, Education Department of Federal Territory of Kuala Lumpur, and Social Welfare Department (JKM) were KPM.600-3/2/3-eras(985), JPNWP.900-6/1/7, and JKMM100/12/5/2:2018/286, respectively.

\section{Research Instruments}

This cross-sectional study involves a researcheradministered approach by using a questionnaire that consists of three prominent parts. Part 1 obtains the socio-demographic and economic information of homeless children. All these questions were administered by the interviewer and answered by the children with the assistance of their guardians or parents.

Part 2 was the 24-hour dietary recall. Respondents were asked to recall the food that they had eaten one day ago to determine their dietary intake adequacy. In these dietary adequacy assessments, an album of food photos with household measurements for the respective foods was provided to the children, guardians, or teachers so that they would have better recognition of the household measurements and amount of food eaten by the children. ${ }^{14}$ In this study, energy intake and a few significant micronutrients in cognitive function were selected such as iron, zinc, and Vitamin B12. Nutritionist Pro Diet Analysis based on Malaysia Food Composition Database was used to analyze the nutrient intake among homeless children. The results were compared with Recommended Nutrient Intake 
(RNI) for Malaysia (2017) ${ }^{15}$. Thus, based on the RNI, energy intake for low active (PAL 1.4) children between aged 7 - 12 ranging between $1410 \mathrm{kcal}$ per day to $1690 \mathrm{kcal}$ per day was selected as a point of reference. Adequacy intake of energy and micronutrients was considered achievable if the mean of nutrient intake has met or exceed $50 \%$ of the RNI.

The cognitive performance test consists of 36 questions with diagrammatic puzzles of Ravens Coloured Progressive Matrices (RCPM). Raven's Coloured Progressive Matrices is a non- verbal test that is used to assess the cognitive performance of children from different language communities as it can measure the ability of children by using nonverbal stimuli. ${ }^{16}$ The interviewer showed children three sets of diagrammatic puzzles. Each of the sets contained 12 matrices from easiest to hardest. In each matrix, there was a missing piece. Six choices for the missing pieces were listed below the matrices. There was only one correct answer and children were required to determine the missing pieces from the choices provided. One score was given for each of the correct answers whereas zero score was given to the wrong answer. Therefore, the range for the total raw score was between 0 and 36 points. The total raw score obtained was then transferred to a standard score using the RCPM table according to age band. Lastly, children were categorized into a different group of qualitative description according to their standard score: $<70$ points (Extremely low), 70-79 points (Borderline), 80 -89 points (Low average), 90-109 points (Average), 110-119 points (High average), 120-129 points (Superior) and $>130$ points (Very superior).

\section{Data Analysis}

A normality test was carried out before data analysis. A Chi-square test was performed in determining the association between dietary adequacy and children's cognitive performance. Fisher's Exact Test was used when more than $20 \%$ of the expected value in each cell is greater than 5 was obtained.

\section{RESULTS AND DISCUSSION}

\section{Demographic profile}

It can be seen from Table I that most of the respondents were female and aged 9 years old.
Table I: Respondents' Socio- demographic Profile $(n=120)$

\begin{tabular}{|c|c|c|}
\hline Variables & $\begin{array}{l}\text { Frequency } \\
\text { (Percent) }\end{array}$ & $\begin{array}{l}\text { Mean } \pm \text { SD } \\
\text { Median } \\
(\text { IQR) }\end{array}$ \\
\hline \multicolumn{3}{|l|}{ Gender } \\
\hline Male & $58(48.3)$ & \\
\hline Female & $62(51.7)$ & \\
\hline Age & & $9(2)$ \\
\hline 7 & $25(20.8)$ & \\
\hline 8 & $26(21.7)$ & \\
\hline 9 & $21(17.5)$ & \\
\hline 10 & $25(20.8)$ & \\
\hline 11 & $11(19.2)$ & \\
\hline \multicolumn{3}{|l|}{ Citizenship } \\
\hline Malaysian & $78(65.0)$ & \\
\hline Non- Malaysian & $18(15.0)$ & \\
\hline Stateless & $24(20.0)$ & \\
\hline \multicolumn{3}{|l|}{ Household income (MYR) } \\
\hline$<500$ & $12(10.0)$ & \\
\hline $501-1000$ & $47(39.2)$ & \\
\hline $1001-1500$ & $21(17.5)$ & \\
\hline$>1500$ & $40(33.3)$ & \\
\hline \multicolumn{3}{|l|}{ Current home } \\
\hline Purpose built flat & $33(27.5)$ & \\
\hline Emergency shelter & $36(30.0)$ & \\
\hline Abandoned building & $0(0.0)$ & \\
\hline $\begin{array}{l}\text { Dwelling with business } \\
\text { premises }\end{array}$ & $0(0.0)$ & \\
\hline Vehicle & $0(0.0)$ & \\
\hline Shop house & $34(28.3)$ & \\
\hline Others & $17(14.2)$ & \\
\hline \multicolumn{3}{|l|}{$\begin{array}{l}\text { Duration of being } \\
\text { homeless/ living in } \\
\text { shelter/renting }\end{array}$} \\
\hline 2 weeks & $1(0.8)$ & \\
\hline 2 months & $1(0.8)$ & \\
\hline 3 months & $1(0.8)$ & \\
\hline 6 months & $1(0.8)$ & \\
\hline 1 year & $17(14.2)$ & \\
\hline 2 years & $11(9.2)$ & \\
\hline 3 years & $8(6.7)$ & \\
\hline 4 years & $11(9.2)$ & \\
\hline 5 years & $9(7.5)$ & \\
\hline 6 years & $8(6.7)$ & \\
\hline 7 years & $12(10.0)$ & \\
\hline 8 year & $10(8.3)$ & \\
\hline 9 years & $12(10.0)$ & \\
\hline 10 years & $10(8.3)$ & \\
\hline 11 years & $8(6.7)$ & \\
\hline \multicolumn{3}{|l|}{ Life satisfaction } \\
\hline Extremely dissatisfied & $1(0.8)$ & \\
\hline Dissatisfied & $27(22.5)$ & \\
\hline Neutral & $22(18.3)$ & \\
\hline Satisfied & $67(55.8)$ & \\
\hline Extremely satisfied & $3(2.5)$ & \\
\hline \multicolumn{3}{|l|}{ Financial support } \\
\hline Yes & $67(55.8)$ & \\
\hline No & $53(44.2)$ & \\
\hline
\end{tabular}




\begin{tabular}{lll}
\hline $\begin{array}{l}\text { Frequency of daily } \\
\text { meal consumption }\end{array}$ & $3(1)$ \\
2 times & $4(3.3)$ & \\
3 times & $63(52.5)$ & \\
4 times & $48(40.0)$ \\
5 times & $5(4.2)$ \\
Food Source* & $90(25.9)$ \\
Homemade & $42(16.3)$ \\
Food stall & $117(45.5)$ \\
School & $20(7.8)$ \\
Daycare & $4(1.6)$ \\
Friends or relatives' & \\
house & $16(6.2)$ \\
Restaurant & $58(22.6)$ \\
Soup kitchen (charity \\
organization)
\end{tabular}

*respondent can answer more than one options

\section{Dietary adequacy of homeless children}

It is somewhat surprising that both age groups of 7 . 9 years old and 10 - 12-year-old had adequate intakes of total energy, as shown in Table II. All energy intakes based on age- and gender-specific had exceeded $50 \%$ of the RNI requirement (more than $66 \%$ ) which indicates as fulfilling diet adequacy. Homeless children in this study had been reported to usually consume fried rice, fried noodles, white rice, fried chicken, and at least one cup of sugary beverage such as tea or rose syrup per day reflecting high intake of carbohydrate and fat sources. This study is in line with previous studies that found that street children had adequate energy intake where their meals were mostly energy-dense, rich in carbohydrate and fat, with little variety of side dishes. ${ }^{17,18} \mathrm{~A}$ possible explanation for this could be that children in both studies had a high intake of energy-dense foods contributing to the total energy adequacy.

This finding is contrary to previous studies which have suggested that homeless children have low energy intake compared to Recommended Daily Allowance (RDA). ${ }^{19}$ Work of previous studies reflects those of Patriasih et al. found that only $20 \%$ of street children in Bandung, Indonesia met energy requirements (i.e. $90-110 \%$ of RDA fulfillment was only considered adequate). ${ }^{20}$ It is encouraging to compare this figure with that found by Yang et al., who found that a majority of the primary school children in Klang Valley aged 10 to 12 years old in Malaysia fail to reach the energy requirement. ${ }^{15} \mathrm{~A}$ possible explanation for the low percentage of daily energy fulfillment among the street children in those previous studies is may be due to the high cut-off points required to meet energy adequacy.
Another important finding was that the respondents aged 10 - 12-year-old boys and girls were unable to achieve more than $85 \%$ of the RNI for iron, as compared to the age group of 7 - 9 years that had exceed $100 \%$ of the RNI. Although they did not reach 100 percent RNI, they were considered as having an adequate intake of iron in their diet $(>50 \%$ of RNI). Following the present results, previous studies have demonstrated that the homeless do achieve an adequate intake of iron. From the previous studies, iron intake of street children in several countries depicts an achievement of nearly or greater than $100 \%$ of iron fulfillment. ${ }^{19,21}$ These findings are somewhat surprising, given the fact that other research shows low fulfillment of iron among those of low socio-economic status. A study in India reported that the percent of adequacy for the iron intake of children within the age of 7- 9 years old was only $32.2 \%$ of RDA requirements, whereas children aged 10 - 12 years old reached $44 \%{ }^{22}$ The low fulfillment of iron intake among those children was due to poverty, poor knowledge of health and nutrition aspects among family, unequal distribution of food, and food insecurity. ${ }^{22}$ The difference of the amount of iron consumption between the present study and previous studies may be explained by the fact that the increasing number of food assistance received from the Malaysian government and non- government organizations. This study has shown that almost all homeless children received food assistance, such as free school meals and soup kitchen foods. Another possible explanation for this is that various common foods in Malaysia contain an easily accessible source of iron for children, including canned sardines, chicken, eggs, anchovies, and so on. ${ }^{15,21}$

Zinc consumption needs improvement, specifically among boys aged $10-12$ years old who only managed to reach less than $50 \%$ of their zinc needs. It is difficult to explain this result, but it might be related to the higher requirement of zinc intake among 10 12-year-old male children, low intake of zinc from the diet, ${ }^{23}$ and picky eating behaviors in their daily $\operatorname{diet}^{24}$. Phytates are also one of the factors contributing to zinc deficiency. ${ }^{25}$ Phytate has a strong inhibitory effect on zinc absorption and is mainly found in staple foods like cereals, rice, corn, and legumes. ${ }^{26}$ Perhaps consumption of higher phytate sources may cause them to have low bioavailability of zinc in their body. In contrast, animal sources food like meat, fish, poultry, and their by-products are higher in zinc contents, which can provide $80 \%$ of 
total the dietary zinc. ${ }^{25,27}$ Thus, to have an optimum intake of zinc, animal source consumption can be increased and phytate contained food should be reduced to maximize zinc absorption in the body.

Both genders for both age groups had an adequate intake of vitamin B12 with the fulfillment of 60.8 and $54 \%$ respectively but requires more improvement. Vitamin B12 obtained from children's daily diet was just based on sufficient needs for their body to carry out its functions. Higher levels of vitamin B12 are required for 10 -12-year-old children because it helps in cell division and normal growth which is essential during the puberty period. ${ }^{28}$
Overall, homeless children had an adequate intake of dietary nutrients, namely energy, iron, zinc, and vitamin B12.

\section{Cognitive performance of homeless children}

Most of the homeless children were in the category of borderline, which is in the second-lowest position out of the seven cognitive categories as shown in Table III. A study done on cognitive function among homeless children in Brazil found that homeless children had poorer cognitive performance compared to non-homeless children. ${ }^{29}$

Table II: Amount and Adequacy of Selected Nutrients Intake of Homeless Children with age group 7 to 9 years old $(n=72)$ and 10 to 12 years old $(n=48)$

\begin{tabular}{|c|c|c|c|c|c|}
\hline \multirow{2}{*}{ Components } & \multirow{2}{*}{ Gender } & \multicolumn{4}{|c|}{$\begin{array}{c}\text { Age Group } \\
7-9 \text { years }(n=72)\end{array}$} \\
\hline & & RNI & $\begin{array}{l}\text { Mean } \pm \text { SD/ } \\
\text { Median (IQR) }\end{array}$ & $\begin{array}{c}\% \text { of } \\
\text { fulfilment }^{\mathrm{a}}\end{array}$ & $\begin{array}{c}\text { Dietary } \\
\text { Adequacy* }\end{array}$ \\
\hline \multirow[t]{2}{*}{ Energy (kcal) } & Boys & 1530.00 & $1212.24 \pm 486.76$ & 79.13 & Adequate \\
\hline & Girls & 1410.00 & $1046.13 \pm 332.62$ & 74.19 & Adequate \\
\hline \multirow[t]{2}{*}{ Iron (mg/day) } & Boys & 9.00 & $13.03(9.15)$ & 144.78 & Adequate \\
\hline & Girls & 9.00 & $11.51(6.00)$ & 127.89 & Adequate \\
\hline \multirow[t]{2}{*}{$\begin{array}{l}\text { Zinc } \\
\text { (mg/day) }\end{array}$} & Boys & 5.70 & $4.37 \pm 2.31$ & 76.67 & Adequate \\
\hline & Girls & 5.60 & $3.37 \pm 1.43$ & 60.18 & Adequate \\
\hline \multirow[t]{2}{*}{$\begin{array}{l}\text { Vitamin B12 ( } \mu \mathrm{g} / \\
\text { day) }\end{array}$} & Both & 2.50 & 1.52 (1.62) & 60.80 & Adequate \\
\hline & \multirow{3}{*}{ Gender } & \multicolumn{4}{|c|}{ Age Group } \\
\hline \multirow{2}{*}{ Components } & & & $10-12$ ye & $(n=48)$ & \\
\hline & & RNI & $\begin{array}{l}\text { Mean } \pm \text { SD/ } \\
\text { Median (IQR) }\end{array}$ & $\%$ of fulfilment ${ }^{a}$ & $\begin{array}{c}\text { Dietary } \\
\text { Adequacy* }\end{array}$ \\
\hline \multirow[t]{2}{*}{ Energy (kcal) } & Boys & 1690.00 & $\begin{array}{l}1122.29 \pm \\
365.30\end{array}$ & 66.41 & Adequate \\
\hline & Girls & 1500.0 & $\begin{array}{c}1135.23 \pm \\
399.99\end{array}$ & 75.68 & Adequate \\
\hline \multirow[t]{2}{*}{ Iron (mg/day) } & Boys & 15.00 & $10.38(8.07)$ & 69.20 & Adequate \\
\hline & Girls & 14.00 & $11.34(5.19)$ & 81.00 & Adequate \\
\hline \multirow[t]{2}{*}{$\begin{array}{l}\text { Zinc } \\
\text { (mg/day) }\end{array}$} & Boys & 7.00 & $3.16 \pm 1.47$ & 45.14 & Inadequate \\
\hline & Girls & 6.30 & $3.76 \pm 1.98$ & 59.68 & Adequate \\
\hline $\begin{array}{l}\text { Vitamin B12 }(\mu \mathrm{g} / \\
\text { day) }\end{array}$ & Both & 3.50 & $1.89(1.51)$ & 54.00 & Adequate \\
\hline
\end{tabular}

a Percentage of fulfilment is calculated by comparing mean and recommended intake based on RNI.

$* \geq 50 \%$ of fulfilment is considered adequate whereas $<50 \%$ of fulfilment is considered inadequate (RNI for Malaysia, 2017). 
Table III: Cognitive Performance of Homeless Children in Klang Valley Categorized into Seven Categories $(n=120)$

\begin{tabular}{lll}
\hline Cognitive Performance & \multicolumn{1}{c}{ Distribution } & Mean \pm SD \\
\cline { 2 - 3 } Categories & $\mathrm{n}(\%)$ & $79.50 \pm 14.178$ \\
\hline Cognitive Score & & \\
Extremely Low $(<70)$ & $27(22.50)$ & \\
Borderline $(70-79)$ & $34(28.30)$ & $27(22.50)$ \\
Low Average $(80-89)$ & $27(22.50)$ \\
Average $(90-109)$ & $4(3.30)$ \\
High Average $(110-119)$ & $1(0.80)$ \\
Superior $(120-129)$ & $0(0.00)$ \\
Very superior $(\geq 130)$ & 4
\end{tabular}

Another study, showed that cognitive performance among homeless children was weaker than housed children. ${ }^{30}$ It is encouraging to compare this finding with those of Tai and Asma who found that majority of fishermen children in Malaysia also had a poor cognitive performance. ${ }^{31}$ It seems possible that these results are due to similar economic characteristics of respondents in both studies where they are from vulnerable groups in Malaysia. Poor cognitive performance of children can be affected by several factors such as insufficient nutrients intake, family socioeconomic status, weight status, and living environment. Homeless people can be categorized in poor and low economic status groups in which they do not have a high education level and skills. Thus, the limited income in the family has become one of the reasons that lead to poor cognitive performance among homeless children. This is because children with low economic status have a lesser opportunity in learning and have fewer chances to expose themselves in cognitive challenging task $^{32}$ causing lack of cognitive stimulation. $^{33}$

The results as shown in Table IV reveal a significant $(p<0.05)$ association between zinc and cognitive performance of the respondents. This is supported by a previous study which stated that low zinc intake could lead to attention deficit among children. ${ }^{34}$ Zinc plays role in the central nervous system as a neurosecretory and cofactor. It forms zinccontaining neurons which can be found in the forebrain. ${ }^{35,36}$ Surprisingly, there was no significant association between other selected nutrients and cognitive ability. The lack of association obtained between energy, iron, and vitamin B12 and cognitive performance can be due to other confounding factors on children's cognitive performance.

In general, the findings of this study do not support the ideas from previous studies which indicated energy, iron, zinc, and vitamin B12 had a significant relationship with cognitive performance. This finding showed that nutrient intake is not the only factor affecting the cognitive performance of homeless children. There may be other prominent factors that influence the cognitive performance of homeless children. The major limitation of this study is that the 24-hour dietary recall taken from certain homeless children may not reflect the exact dietary intake during their homeless period. No iodine dietary intake was assessed as no information of it is available in the Malaysian food composition database. It is suggested that further study on iodine adequacy and cognitive performance of homeless children can be carried out using urinary iodine tests to determine the level of iodine in the body. Despite its limitations, this study certainly contributes to our understanding of the diet adequacy and cognitive performance of these homeless children.

Table IV: Association between Dietary Adequacy and Cognitive Performance $(n=120)$

\begin{tabular}{|c|c|c|c|c|c|}
\hline \multirow{2}{*}{ Nutrients } & & \multicolumn{2}{|c|}{$\begin{array}{c}\text { Cognitive } \\
\text { Performance }\end{array}$} & \multirow[t]{2}{*}{$x^{2}$} & \multirow[t]{2}{*}{$\begin{array}{c}\text { p- } \\
\text { value }\end{array}$} \\
\hline & & Poor & $\begin{array}{l}\text { Not } \\
\text { Poor }\end{array}$ & & \\
\hline \multirow[t]{2}{*}{ Energy } & Adequate & 74 & 26 & 0.136 & 0.712 \\
\hline & Inadequate & 14 & 6 & & \\
\hline \multirow[t]{2}{*}{ Iron } & Adequate & 79 & 29 & 0.019 & 1.000 \\
\hline & $\begin{array}{l}\text { Inade- } \\
\text { quate }\end{array}$ & 9 & 3 & & \\
\hline \multirow[t]{2}{*}{ Zinc } & Adequate & 58 & 14 & 4.801 & $0.028^{*}$ \\
\hline & Inadequate & 30 & 18 & & \\
\hline \multirow[t]{2}{*}{$\begin{array}{l}\text { Vitamin } \\
\text { B12 }\end{array}$} & Adequate & 60 & 16 & 3.341 & 0.068 \\
\hline & Inadequate & 28 & 16 & & \\
\hline
\end{tabular}

\section{CONCLUSION}

This study had shown that homeless children have adequate intake for energy, iron, and vitamin B12. Most homeless children are categorized in the borderline category for their cognitive performance. There were no associations found between the energy, iron, and Vitamin B12 adequacy and cognitive performance of homeless children except for zinc adequacy. 


\section{ACKNOWLEDGMENTS}

The authors would like to express their sincere gratitude to all homeless center points and also the respondents for their participation, full cooperation, and patience during the study.

\section{REFERENCES}

1. Irsyad A. 2016. Numbers Of Homeless People Increased By Three Fold In Kuala Lumpur, What Are We Doing To Curb The Problem? Retrieved from http://malaysiandigest.com/ features/596717-numbers-of-homeless-peopleincreased-by-three-fold-in-kuala-lumpur-whatare-we-doing-to-curb-the-problem.html (accessed 6 April 2018).

2. Arfa Y. 2015. Number of Homeless in $\mathrm{KL}$ on the Rise, says MP. The Rakyat Post. Retrieved from http://www.therakyatpost.com/ news/2015/02/27/number-of-homeless-in-kl-onthe-rise-says-mp/ (Accessed 6 April 2018).

3. Penang Institute. 2015. Homelessness in Our Cities. Penang Institute.

4. Rafiza BM, Awang J, Ahmad SL et al. Homeless Requirement of Religious Support System. Journal of Sultan Alauddin Sulaiman Shah. 2017; 40(1): 82-92.

5. Castro- Quezada I, Roman- Vinas B and SerraMajem L. The Mediterranean Diet and Nutritional Adequacy: A Review. Nutrients. 2014; 6(1): 231 248.

6. Ochola S. and Masibo PK. Dietary Intake of Schoolchildren and Adolescents in Developing Countries. Annuals of Nutrition and Metabolism. 2014; 64(2): 24-40.

7. McAfee AJ, Mulhern MS, McSorley EM et al. Intakes and Adequacy of Potentially Important Nutrients for Cognitive Development among 5year-old Children in the Seychelles Child Development and Nutrition Study. Public Health Nutrition. 2012; 15(9): 1-15.

8. Hutagulung FD and Isa ZM. Cognitive Ability among Preschool Children in Kuala Lumpur Malaysia. Social Interaction and Networking in Cyber Society. 2017; 15-25.

9. Mitra- Ganguli T, Kalita S, Bhushan S et al. A Randomised, Double- Blind Study Assessing Changes in Cognitive Function in Indian School Children Receiving a Combination of Bacopa Monnieri and Micronutrient Supplementation vs Placebo. Frontiers in Pharmacology. 2017; 8
(678): 1-13.

10. Black MM. Micronutrient Deficiencies and Cognitive Functioning 1, 2. Journal of Nutrition. 2003; 133 (11suppl 2): 1-9.

11. Khor GL and Misra S. Micronutrient Interventions on Cognitive Performance of Children aged 5-15 years in Developing Countries. Asia Pacific Journal of Clinical Nutrition. 2012; 21 (4): 476486.

12. Benton. The Influence of Dietary Status on the Cognitive Performance of Children. Molecular Nutrition and Food Research. 2010; 54: 457-470.

13. Rusidah S, Wan Nazaimoon WM, Ahmad AZ et al. Iron Deficiency Status and lodised Salt Consumption in Malaysia: Findings from a National lodine Deficiency Disorders Survey. Asia Pacific Journal of Clinical Nutrition. 2010; 19 (4): 578-585.

14. Yang WY, Burrows $T$, MacDonald-Wicks $L$ et al. Body Weight Status and Dietary Intake of Urban Malay Primary School Children: Evidence from the Family Diet Study. Children. 2017; 4, 5: 116.

15. Recommended Nutrient Intakes for Malaysia. 2017. National Coordinating Committee on Food and Nutrition.

16. Raven J. Coloured Progressive Matrices and Crichton Vocabulary Scale Manual. London: Pearson. 2004.

17. Kalimbira AA and Chipwatali. Dietary Pattern and Prevalence of Wasting Among Street Children in Lilongwe, Malawi. African Journal of Food Agriculture Nutrition and Development. 2007; 7(1): 1-14.

18. Skinner JD, Carruth BR, Bounds W et al. Children's Food Preferences: A Longitudinal Analysis. Journal of the American Dietetic Association. 2002; 102 (11): 1638- 1647.

19. Greksa LP, Rafiqul Islam ABM, Okamoto $R$ et al. Dietary Patterns and Dietary Adequacy of Street Children in Dhaka, Bangladesh. Ecology of Food and Nutrition. 2017.

20. Patriasih R, Widiaty I, Dewi M et al. Nutrients Intake and Nutritional Status of Street Children in Bandung. Journal of Nutrition and Food. 2010; 5(3): 177-183.

21. Andersson M, Takkouche B, Egli I et al. Current Global lodine Status and Progress Over the Last Decade Towards the Elimination of lodine Deficiency. Bulletin of the World Health Organization. 2005; 83(5): 518-525.

22. Kulsum A, Lakshmi J and Prakash J. Dietary 
Adequacy of Indian Children Residing in an Urban Slum - Analysis of Proximal and Distal Determinants. Ecology of Food and Nutrition. 2009; 48: 161-177.

23. Larson CP, Roy SK, Khan Al et al. Zinc Treatment to Under- five Children Applications to Improve Child Survival and Reduce Burden of Disease. Journal of Health, Population and Nutrition. 2008; 26(3): 356- 365.

24. Volger $S$, Sheng XY, Tong LM et al. Nutrient Intake and Dietary Patterns in Children 2.5-5 Years of Age with Picky Eating Behaviours and Low Weight-For-Height. Asia Pacific Journal of Clinical Nutrition. 2017; 26 (1): 104- 109.

25. Sandstead HH and Freeland-Graves JH. Dietary Phytate, Zinc and Hidden Zinc Deficiency. Journal of Trace Elements in Medicine and Biology. 2014; 28: 414- 417.

26. Lonnerdal B. Dietary Factors Influencing Zinc Absorption. American Society for Nutritional Sciences. 2000; 1378S-1383S.

27. Jung A, Spira D, Thiessen ES et al. Zinc Deficiency is Associated with Depressive Symptoms Results from the Berlin Aging Study II. Journal of Gerontology: Medical Sciences. 2016; 72(8): 1149-1154.

28. Monsen ALB and Ueland PM. Cobalamin Status in Children. Journal of Inherited Metabolic Disease. 2011; 34: 111- 119.

29. Borges-Murphy CS, Pontes F, Stivanin L et al. Auditory Processing in Children and Adolescents in Situations of Risk and Vulnerability. Sao Paulo Medical Journal. 2012; 130:151-158.

30. Yu MS, North CS, LaVesser PD et al. A Comparison Study of Psychiatric and Behaviour Disorder and Cognitive Ability among Homeless and Housed Children. Community Mental Health Journal. 2008; 44 (1): 1 - 10.

31. Tai SW and Ali A. Breakfast Consumption and Its Relationship with Cognitive Performance among Fishermen's Children in Terengganu. Malays. Applied Biology. 2018; 47(4): 24-34.

32. Bradley RH and Corwyn RF. Socioeconomic Status and Child Development. Annual Review of Psychology. 2002; 53: 371- 399.

33. Burger K. How does Early Childhood Care and Education Affect Cognitive Development? An International Review of the Effects of Early Interventions for Children from Different Social Backgrounds. Early Childhood Research Quarterly. 2010; 25(2): 140- 165.
34. Arnold LE and DiSilvestro RA. Zinc in AttentionDeficit/ Hyperactivity Disorder. Journal of Child and Adolescent Psychopharmacology. 2005; 15 (4): 619- 627.

35. Frederickson CJ, Suh SW, Sliva D et al. Importance of Zinc in the Central Nervous System: The Zinc- Containing Neuron. Journal of Nutrition. 2000; 130: 1471s- 1483s.

36. Huskisson E, Maggini S and Ruf M. The Influence of Micronutrients on Cognitive Function and Performance. The Journal of International Medical Research. 2007; 35: 1- 19. 